\title{
EVALUASI PERLAKUAN AKUNTANSI TABUNGAN HAJI PADA PT. BANK RAKYAT INDONESIA (PERSERO) TbK KANTOR CABANG SOASIO KOTA TIDORE KEPULAUAN
}

\author{
Santi Ali M. Nur ${ }^{1}$, Sifrid S. Pangemanan ${ }^{2}$, Hendrik Gamaliel ${ }^{3}$ \\ ${ }^{1,2,3}$ Jurusan Akuntansi, Fakultas Ekonomi dan Bisnis, Universitas Sam Ratulangi, Jl. Kampus Bahu, Manado, \\ 95115, Indonesia \\ E-mail : santiali023@yahoo.co.id
}

\begin{abstract}
Hajj savings is the product issued savings bank to help communities or clients wishing to the annual haj pilgrimage. This study aims to evaluation accounting treatment savings haji he would do to PT. Bank rakyat indonesia (Persero) Tbk Soasio Branch Ooffices Tidore city. The method of analysis that is the method used descriptive with a kind of qualitative research was conducted. The results of the study obtained that the mechanisms of accounting treatment (recognition, measurement and disclosure) savings over the cancellation of hajj pilgrimage before and after customers listed as a candidate hajj pilgrims in the ministry of religious affairs and also the mechanism of accounting treatment hajj over saving hajj after the cancellation of registration are already in accordance with Generally Accepted Accounting Principle.
\end{abstract}

Keywords : Evaluation, Accounting Treatment, Hajj Saving

\section{PENDAHULUAN}

Indonesia merupakan salah satu negara dengan penduduk yang mayoritas beragama islam. Salah satu ibadah yang dilaksanakan oleh umat muslim adalah menunaikan ibadah haji. Namun, dalam melaksanakan ibadah haji, biaya yang dibutuhkan tidak sedikit itulah kenapa tidak semua orang dapat menjalankan ibadah haji walaupun mereka sangat menginginkannya. Masyarakat dengan kondisi ekonomi rata-rata yang ingin menunaikan ibadah haji harus menabung terlebih dahulu dalam tempo waktu yang cukup lama untuk bisa mendaftar menjadi Calon Jamaah Haji. Ibadah haji harus dijalankan oleh mereka yang mampu. Mampu dalam hal ini diartikan tidak hanya mampu secara fisik tapi juga secara financial.

Banyaknya masyarakat dari berbagai penjuru dunia yang ingin menunaikan ibadah haji, bahkan setiap tahun semakin bertambah banyak umat islam yang ingin menjalankan ibadah haji, termasuk masyarakat di Indonesia. Oleh sebab itu, pemerintah Arab Saudi telah menetapkan untuk membatasi jumlah jamaah haji yang akan berangkat haji dengan cara menetapkan aturan kuota bagi setiap negara jamaah haji. Dengan adanya aturan tersebut, negara-negara yang akan mengirimkan jamaah haji harus membatasi jumlahnya sesuai dengan kuota yang telah ditentukan. Bank dalam rangka membantu masyarakat yang ingin menunaian ibadah haji mengeluarkan produk tabungan haji. Bukan hanya bank syariah tapi bank konvensional juga berlomba-lomba membuat inovasi dari produk tabungan haji untuk menarik minat masyarakat agar membuka tabungan haji. Nasabah yang ingin mendapatkan tabungan haji pada Bank BRI hanya perlu membuka rekening tabungan haji dengan mendaftarkan diri langsung pada bank BRI terdekat dengan menyiapkan dokumen dan beberapa hal yang menjadi syarat dan ketentuan tabungan haji. Syarat dan ketentuan tabungan haji Bank BRI diantaranya mengisi formulir aplikasi pembukaan rekening, identitas diri (KTP), dan setoran awal sebesar Rp 100.000. Ketika saldo telah mencapai Rp 25.100.000,- maka nasabah akan dibantu untuk penginputan data sebagai calon jamaah haji untuk mendapatkan nomor porsi haji. 
Nasabah yang telah mendaftarkan tabungan haji dan mulai menabung, adakalanya ada beberapa nasabah yang membatalkan haji dan menutup tabungan haji sebelum berangkat haji. Hal ini dikarenakan beberapa alasan, diantaranya pembatalan dilakukan karena meninggal dunia, sakit parah ataupun tanpa alasan. Pembatalan haji ada yang dilakukan oleh nasabah yang belum terdafar sebagai CJH di Depag maupun nasabah yang telah terdaftar sebagai CJH di Depag. Pembatalan tabungan haji tersebut tidak boleh dilakukan sesuka nasabah karena ada prosedur dan langkah - langkah yang harus diikuti oleh nasabah dengan persyaratan yang telah ditentukan. Nasabah harus mengikuti prosedur hingga selesai agar pihak bank dapat mengembalikan uang tabungan nasabah karena pembatalan tersebut.

Pembatalan haji karena beberapa alasan diatas dapat terjadi kapan saja, baik sebelum nasabah terdaftar di Departemen Agama maupun setelah nasabah menjadi Calon Jamaah Haji $(\mathrm{CJH})$. Prosedur yang harus dilakukan oleh nasabah ketika membatalkan tabungan haji juga berbeda jika nasabah belum ataupun telah terdaftar pada Departemen Agama. Karena jika sudah terdaftar di Departemen Agama nasabah harus menyelesaikan prosedur yang telah ditentukan di Departemen Agama kemudian pihak bank akan mengembalikan uang tabungan nasabah. Berbeda jika nasabah belum terdaftar di Departemen Agama, maka nasabah hanya perlu menyelesaikan prosedur pembatalan dengan pihak bank kemudian menerima pengembalian uang tabungan tersebut. Setelah dilakukan pembatalan haji dan penutupan rekening tabungan haji karena beberapa alasan diatas, tidak menutup kemungkinan nasabah akan kembali membuka rekening tabungan haji dan mendaftarkan haji. Untuk membuka tabungan haji setelah dilakukan pembatalan haji nasabah harus mengetahui mekanisme yang dilakukan oleh bank.

\section{TINJAUAN PUSTAKA}

Definisi Akuntansi. Akuntansi adalah ilmu yang mempelajari tentang pencatatan, penggolongan, dan penyajian mengenai suatu informasi dan mengukur berdasarkan bentuk mata uang untuk transaksi-transaksi keuangan perusahaan dan mengkomunikasikan hasilnya. (Tanor, 2015).

Definisi Akuntansi keuangan. Akuntansi keuangan adalah aktivitas perusahaan yang meliputi proses pencatatan sampai menganalisis data -data keuangan perusahaan dan output yang dihasilkan dari aktivitas tersebut yaitu laporan keuangan. Laporan keuangan ini akan digunakan oleh pihak internal dan eksternal perusahaan dalam pengambilan keputusan ekonomi. (BINUS University, 2016).

Prinsip Akuntansi Berterima Umum (PABU). Prinsip Akuntansi yang berlaku umum (PABU) adalah sekumpulan aturan, prinsip dan standar akuntansi yang digunakan oleh suatu perusahaan dalam penyusunan laporan keuangan. (Flood, 2014).

\section{Tabungan Haji}

Definisi Tabungan Haji. Tabungan adalah suatu bentuk simpanan uang dengan menyisihkan sebagian pendapatan untuk masa yang akan datang. Sedangkan haji adalah salah satu bentuk ibadah untuk mengunjungi Baitullah dengan melakukan seluruh syarat dan rukun wajib haji. Maka tabungan haji adalah suatu simpanan yang dilakukan oleh seseorang yang ingin menjalankan ibadah haji. (Kholid, 2013).

Peraturan Tabungan Haji. Peraturan mengenai tabungan haji diatur dalam Peraturan Pemerintah Republik Indonesia Nomor 5 Tahun 2018 tentang Pelaksanaan Undang-undang Nomor 34 Tahun 2014 tentang Pengelolaah Keuangan Haji. Hal tersebut diatur dalam pasal 12 ayat 1 yang berbunyi " Setiap warna negara yang akan menunaikan ibadah haji harus membuka tabungan jamaah haji pada BPS BPIH". Dengan demikian maka setiap warga yang ingin melaksakan ibadah haji wajib memiliki tabungan haji. (UU No. 5 Tahun 2018). 
Mekanisme Pendaftaran Tabungan Haji. Menurut Setiawan (2018), pendaftaran tabungan haji dapat dilakukan dengan syarat dan ketentuan sebagai berikut : (1) mengisi formulir aplikasi pembukaan rekening; (2) identitas diri : Kartu Tanda Penduduk (KTP) berbasis NIK dan NPWP; (3) setoran awal sebesar Rp 100.000; dan (4) gratis biaya administrasi.

Perlakuan Akuntansi Tabungan Haji. Perlakuan akuntansi tabungan haji terdiri dari proses pengakuan, pencatatan, pengukuran dan pengungkapan. Pada proses pencatatan tabungan haji akan dilaporkan dengan mencatat jurnal pada saat transaksi, diantaranya pada saat nasabah melakukan setoran awal, setoran untuk mendapatkan nomor porsi keberangkatan haji, dan pada saat pelunasan. Pada saat proses pengukuran, nasabah yang mendaftar untuk tabungan haji dan pihak bank akan mengakui setoran awal sebagai dana kewajiban nasabah. Sedangkan pada proses pengungkapan yaitu saat nasabah mendaftar serta menyetorkan tabungan haji kemudia mendapatkan nomor porsi haji pada saat dana telah mencukupi sesuai dengan ketentuan. (Astari, 2013).

\section{METODE PENELITIAN}

Jenis Penelitian. Penelitian dilaksanakan dengan cara menggambarkan mekanisme perlakuan akuntansi yang dimulai dari proses pengakuan, pengukuran hingga pengungkapan. Untuk mengevaluasi perlakuan akuntansi dari tabungan haji, penelitian ini dilakukan dengan mengumpulkan data-data yang diperlukan seperti mekanisme pembatalan haji dan pendaftaran haji, siklus pencatatan akuntansi serta kemudian menguraikannya secara keseluruhan.

Tempat dan Waktu Penelitian. Penelitian dilaksanakan di PT. Bank Rakyat Indonesia (Persero) Tbk Kantor Cabang Soasio Kota Tidore Kepulauan bertempat di Jl. Pattimura no.1 Kota Tidore Kepulauan. Waktu penelitian dimulai pada bulan Juni 2018 hingga Juli 2018.

Prosedur Penelitian. Proses identifikasi permasalahan, menetapkan fokus masalah, melaksanakan penelitian, mengolah dan menganalisis data, dan melaporkan hasil penelitian.

Jenis Data. Jenis data yang digunakan dalam penelitian ini adalah data kualitatif, diantaranya adalah : (1) profil Bank BRI; (2) visi misi; (3) struktur organisasi; (4) mekanisme pembatalan haji; (5) mekanisme pendaftaran kembali setelah dilakukan pembatalan haji; dan (6) siklus pencatatan akuntansi tabungan haji.

Sumber Data. Pada penelitian ini menggunakan data primer yaitu data berupa hasil wawancara langsung penulis dengan beberapa pihak yang terkait. Seperti wawancara dengan Costumer Service Bank, Teller, dan bagian dana dan jasa.

Teknik Pengumpulan Data. Pengumpulan data yang digunakan dalam penelitian ini menggunakan teknik sebagai berikut.

1. Wawancara. Yakni dengan dilakukannya proses tanya jawab yang berlangsung secara lisan kepada pihak-pihak narasumber. dalam hal ini dilakukan wawancara dengan bagian operasional bank untuk mengetahui mekanisme yang digunakan bank dalam pembatalan haji sebelum dan setelah nasabah terdaftar sebagai CJH di Depag serta mekanisme pendaftaran kembali tabungan haji setelah dilakukan pembatalan. selain itu, melakukan wawancara untuk mengetahui proses pencatatan jurnal transaksi tabungan haji dan perlakuan akuntansi yang dilakukan bank dalam tabungan haji.

2. Dokumentasi pengumpulan informasi atau data dilakukan dengan cara mengumpulkan dokumen-dokumen berupa profil Bank BRI Kantor Cabang Soasio, visi misi perusahaan, sejarah berdirinya instansi, dan struktur organisasi.

Teknik Analisis Data. Analisis data dilakukan dengan cara mengumpulkan, menyajikan, dan menganalisis data sehingga diperoleh gambaran yang cukup jelas mengenai 
permasalahan yang diangkat dengan melakukan perbandingan-perbandingan antara teori-teori dengan kenyataan yang terjadi dilapangan.

\section{HASIL ANALISIS DAN PEMBAHASAN}

\subsection{Hasil Analisis}

Mekanisme Pengakuan dan Pengukuran Tabungan haji Atas Pembatalan Haji

Sebelum Nasabah Terdaftar di Departemen Agama. Pembatalan haji adalah suatu proses untuk membatalkan kegiatan atau keberangkatan haji yang dilakukan oleh Calon Jamaah Haji (CJH) sebelum waktu keberangkatan haji tiba. Pembatalan haji yang dilakukan oleh CJH juga berdampak terhadap penutupan rekening tabungan haji yang dimiliki oleh nasabah $\mathrm{CJH}$ tersebut. Hal ini dikarenakan setiap nasabah $\mathrm{CJH}$ yang telah membatalkan haji harus menutup rekening tabungan hajinya. Adapun penyebab atau alasan terjadinya pembatalan haji diantaranya $\mathrm{CJH}$ meninggal dunia, sakit parah ataupun alasan lainnya. Pembatalan haji yang dilakukan nasabah bisa terjadi kapan saja baik sebelum nasabah terdaftar sebagai CJH maupun setelah nasabah terdaftar sebagai CJH di Departemen Agama. Prosedur dan mekanisme yang dilakukan nasabah juga berbeda sebelum dan setelah nasabah terdaftar sebagai CJH di Depag. Jika nasabah belum terdaftar sebagai CHJ di Depag prosedur pembatalan haji dan penutupan rekening tabungan haji hanya dilakukan nasabah dengan pihak bank. Pembatalan tabungan haji yang dilakukan nasabah sebelum nasabah terdaftar sebagai Calon Jamaah haji di Departemen Agama dapat dilakukan antara nasabah dengan pihak bank, mekanisme pembatalan tersebut sebagai berikut:

a. Nasabah datang ke bank dengan tujuan pembatalan haji harus membawa buku tabungan haji dan KTP.

b. Nasabah mengisi aplikasi penutupan rekening tabungan haji di costumer service.

c. Nasabah yang melakukan penutupan rekening tabungan haji dikenakan biaya administrasi sebesar Rp 50.000.

d. Nasabah menerima uang tabungan haji yang diberikan oleh teller sebesar jumlah yang tertera pada rekening tabungan haji nasabah yang telah dikurangi biaya administrasi sebesar Rp 50.000.

e. Setelah menerima uang pengembalian tabungan haji dari teller, tabungan haji nasabah akan ditutup secara otomatis.

Mekanisme pembatalan haji pada saat nasabah belum terdaftar sebagai CJH di Departemen Agama pada Bank BRI, proses pengakuan dan pengukuran tabungan haji adalah sebagai berikut :

a. Pengakuan tabungan haji atas pembatalan haji diakui pada saat nasabah melakukan pembatalan haji dan penutupan rekening tabungan haji, bank mencatat sebagai kewajiban atas penutupan rekening tabungan haji.

b. Pada saat penutupan rekening tabungan haji nasabah dikenakan biaya sebesar Rp 50.000,dan diakui bank sebagai biaya administrasi yang akan menjadi saldo mengendap yang tidak dapat diambil oleh nasabah pemegang rekening. Biaya administrasi tersebut dikurangi secara langsung pada saat pengembalian uang tabungan haji.

c. Pengukuran tabungan haji atas pembatalan haji diukur sebesar jumlah nilai yang tertera pada passbook tabungan haji nasabah setelah dikurangi dengan biaya administrasi penutupan tabungan. 
Berikut jurnal pencatatan akuntansi untuk transaksi tabungan haji yang dilakukan oleh bank :

Jurnal pada saat pembukaan rekening dan setoran awal

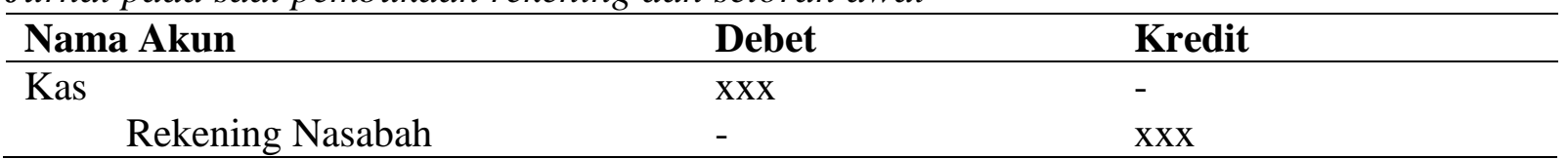

Artinya di debet, yaitu uang kas yang berada di bank bertambah dan rekening tabungan haji nasabah yang berada di kredit artinya saldo tabungan nasabah bertambah.

Jurnal untuk pembatalan haji dan penutupan rekening sebelum nasabah terdaftar sebagai CJH di Depag

\begin{tabular}{lll}
\hline Nama Akun & Debet & Kredit \\
\hline Rekening Nasabah & $\mathrm{xxx}$ & - \\
Biaya administrasi & - & $\mathrm{xxx}$ \\
Kas & - & $\mathrm{xxx}$ \\
\hline
\end{tabular}

Artinya di debet rekening tabungan haji nasabah yang berarti bahwa rekening tabungan haji nasabah yang berada di bank berkurang sedangkan di kredit kas yang berarti uang kas yang berada di bank berkurang karena adanya pembayaran akibat dari pembatalan haji dan penutupan rekening tabungan haji yang dilakukan oleh nasabah, kemudian di kreditkan pula biaya administrasi yang akan menjadi saldo mengendap di rekening.

Mekanisme Pengakuan dan Pengukuran Tabungan haji Atas Pembatalan Haji Setelah Nasabah Terdaftar di Departemen Agama. Pembatalan haji adalah suatu proses untuk membatalkan kegiatan atau keberangkatan haji yang dilakukan oleh Calon Jamaah Haji (CJH) sebelum waktu keberangkatan haji tiba. Pembatalan haji yang dilakukan oleh CJH juga berdampak terhadap penutupan rekening tabungan haji yang dimiliki oleh nasabah $\mathrm{CJH}$ tersebut. Hal ini dikarenakan setiap nasabah $\mathrm{CJH}$ yang telah membatalkan haji harus menutup rekening tabungan hajinya. Adapun penyebab atau alasan terjadinya pembatalan haji diantaranya CJH meninggal dunia, sakit parah ataupun alasan lainnya. Pembatalan haji yang dilakukan nasabah bisa terjadi kapan saja baik sebelum nasabah terdaftar sebagai CJH maupun setelah nasabah terdaftar sebagai CJH di Departemen Agama. Prosedur dan mekanisme yang dilakukan nasabah juga berbeda sebelum dan setelah nasabah terdaftar sebagai CJH di Depag. Jika nasabah telah terdaftar sebagai CHJ di Depag prosedur pembatalan haji dilakukan nasabah dengan pihak Depak terlebih dahulu dan kemudian untuk pengembalian uang tabungan haji dilakukan oleh nasabah dengan pihak bank. Pembatalan tabungan haji yang dilakukan nasabah ketika nasabah telah terdaftar sebagai Calon Jamaah Haji di Departemen Agama dilakukan oleh nasabah dengan pihak Departemen Agama terlebih dahulu kemudian untuk pengembalian uang tabungan haji dilakukan antara nasabah dengan pihak bank sesuai dengan syarat dan ketentuan yang telah ditetapkan. Mekanisme pembatalan tabungan haji sebagai berikut :

a. Nasabah datang ke Kantor Departemen Agama Kabupaten/Kota.

b. Nasabah mengajukan surat permohonan pembatalan kepada Kandepag kab/kota dengan melampirkan dokumen sebagai berikut : (1) Bukti setoran awal BPIH asli lembar pertama; (2) Surat pernyataan batal dari Calon Jamaah Haji bermaterai Rp 6000,-; (3) Surat kuasa bermaterai Rp 6000,- dari Calon Jamaah Haji yang bersangkutan dan diketahui oleh Lurah/Kepala Desa setempat; dan (4) Fotocopi surat kematian dan surat keterangan ahli waris bagi yang batal karena meninggal dunia. 
c. Setelah mengajukan surat permohonan pembatalan kepada Kandepag, nasabah akan menerima surat pemberitahuan dari Kandepag.

d. Setelah menerima surat pemberitahuan, nasabah harus datang ke bank dengan membawa surat pemberitahuan pembatalan haji tersebut dengan buku tabungan serta KTP.

e. Bank/Costumer Service menerima surat menerima surat pemberitahuan dari Kanwil Depag untuk dilakukan pemindahbukuan dana dari rekening menteri agama ke rekening Calon Jamaah Haji.

f. Costumer Service melakukan login kedalam sistem untuk melakukan pembatalan haji.

g. Berdasarkan surat tersebut, buat tiket transaksi dan lakukan pemindahbukuan dari rekening menteri agama ke rekening nasabah sesuai jumlah nilai yang telah disetorkan.

h. Memberikan stempel tanda batal pada form/tiket transaksi pemindahbukuan.

i. Setelah itu nasabah harus menunggu hingga transaksi pemindahbukuan tersebut berhasil, hal itu biasanya membutuhkan proses yang lama, sehingga nasabah biasanya akan diminta pihak bank untuk kembali lagi nanti jika sudah mendapat konfirmasi dari pihak bank.

j. Setelah mendapat konfirmasi dari pihak bank, nasabah harus datang ke bank/ Teller dengan membawa buku tabungan haji serta KTP.

k. Setelah Teller mengkonfirmasi berkas-berkas nasabah dan telah sesuai maka teller akan langsung mengembalikan uang tabungan nasabah.

1. Pengembalian uang tabungan tersebut tidak sepenuhnya karena akan dikurangi dengan biaya administrasi sebesar RP 50.000,- pada saat pengembalian tersebut.

m. Setelah itu maka buku tabungan haji nasabah secara otomatis akan ditutup.

Mekanisme pembatalan haji pada saat nasabah telah terdaftar sebagai CJH di Departemen Agama pada Bank BRI, proses pengakuan dan pengukuran tabungan haji adalah sebagai berikut :

a. Pengakuan tabungan haji atas pembatalan haji diakui pada saat nasabah melakukan pembatalan haji dan penutupan rekening tabungan haji, pihak bank kemudian akan melakukan pengembalian uang tabungan haji. Pengembalian tersebut dilakukan ketika transaksi pemindahbukuan dari rekening Menteri Agama ke rekening Nasabah telah berhasil, hal ini dilihat dari saldo buku tabungan Nasabah yang telah bertambah. Bank mencatat sebagai kewajiban atas penutupan rekening tabungan haji.

b. Pada saat penutupan rekening tabungan haji nasabah dikenakan biaya sebesar Rp 50.000,dan diakui bank sebagai biaya administrasi yang akan menajdi saldo mengendap yang tidak dapat diambil oleh nasabah pemegang rekening. Biaya administrasi tersebut dikurangi secara langsung pada saat pengembalian uang tabungan haji.

c. Pengukuran tabungan haji atas pembatalan haji diukur sebesar jumlah nilai yang tertera pada passbook tabungan haji nasabah setelah transaksi pemindahbukuan dari rekening Menteri Agama ke rekening Nasabah telah berhasil, pengukuran juga dilakukan setelah dikurangi dengan biaya administrasi penutupan tabungan.

Berikut jurnal pencatatan akuntansi untuk transaksi tabungan haji yang dilakukan oleh bank :

Jurnal pada saat pembukaan rekening dan setoran awal

\begin{tabular}{|c|c|c|}
\hline Nama Akun & Debet & Kredit \\
\hline Kas & $\mathrm{XXX}$ & - \\
\hline Rekening Nasabah & - & $\mathrm{xxx}$ \\
\hline
\end{tabular}

Artinya di debet, yaitu uang kas yang berada di bank bertambah dan rekening tabungan haji nasabah yang berada di kredit artinya saldo tabungan nasabah bertambah. 
Jurnal pada saat setoran untuk mendapatkan nomor porsi keberangkatan dan terdaftar sebagai CJH di Depag

\begin{tabular}{cll}
\hline Nama Akun & Debet & Kredit \\
\hline Rekening Nasabah & $\mathrm{xxx}$ & - \\
Rekening Menteri Agama & - & $\mathrm{xxx}$ \\
\hline
\end{tabular}

Artinya di debet rekening tabungan haji adalah rekening tabungan haji nasabah yang berada di bank berkurang karena dipindahbukukan ke rekening Menteri Agama Kantor Pusat.

Jurnal pada saat pengembalian uang tabungan haji nasabah dan penutupan rekening tabungan haji

\begin{tabular}{cll}
\hline Nama Akun & Debet & Kredit \\
\hline Rekening Nasabah & $\mathrm{xxx}$ & - \\
Biaya administrasi & - & $\mathrm{xxx}$ \\
Kas & - & $\mathrm{xxx}$ \\
\hline
\end{tabular}

Artinya di debet rekening tabungan haji nasabah yang berarti bahwa rekening tabungan haji nasabah yang berada di bank berkurang sedangkan di kredit kas yang berarti uang kas yang berada di bank berkurang karena adanya pembayaran akibat dari penutupan yang dilakukan oleh nasabah, kemudian di kreditkan pula biaya administrasi yang akan menjadi saldo mengendap di rekening.

Mekanisme Pengakuan dan Pengukuran Pendaftaran Kembali Tabungan Haji Setelah Pembatalan. Pembatalan haji adalah suatu proses untuk membatalkan kegiatan atau keberangkatan haji yang dilakukan oleh Calon Jamaah Haji (CJH) sebelum waktu keberangkatan haji tiba. Pembatalan haji yang dilakukan oleh $\mathrm{CJH}$ juga berdampak terhadap penutupan rekening tabungan haji yang dimiliki oleh nasabah $\mathrm{CJH}$ tersebut. Hal ini dikarenakan setiap nasabah $\mathrm{CJH}$ yang telah membatalkan haji harus menutup rekening tabungan hajinya. Adapun penyebab atau alasan terjadinya pembatalan haji diantaranya $\mathrm{CJH}$ meninggal dunia, sakit parah ataupun alasan lainnya. Pembatalan haji yang dilakukan nasabah bisa terjadi kapan saja baik sebelum nasabah terdaftar sebagai CJH maupun setelah nasabah terdaftar sebagai CJH di Departemen Agama. Prosedur dan mekanisme yang dilakukan nasabah juga berbeda sebelum dan setelah nasabah terdaftar sebagai CJH di Depag. Jika nasabah belum terdaftar sebagai CJH di Depag makan prosedur pembatalan haji hanya dilakukan nasabah dengan pihak bank. Namun, jika nasabah telah terdaftar sebagai CHJ di Depag prosedur pembatalan haji dilakukan nasabah dengan pihak Depak terlebih dahulu dan kemudian untuk pengembalian uang tabungan haji dilakukan oleh nasabah dengan pihak bank. Nasabah yang telah melakukan pembatalan haji dengan alasan sakit atapun alasan lainnya, dapat mendaftarkan kembali pemberangkatan haji dan membuka rekening haji yang baru di Bank BRI. Mekanisme pendaftaran tabungan haji setelah dilakukan pembatalan haji sama seperti pendaftaran tabungan haji sebelumnya atau sama seperti pertama kali melakukan pendaftran tabungan haji. Syarat dan dokumen yang harus disiapkan juga sama. Berikut mekanisme dan persyaratan pendaftaran tabungan haji :

a. Nasabah datang ke bank/Costumer Service dengan membawa Kartu Tanda Pengenal (KTP), Kartu Keluarga dan NPWP.

b. Nasabah mengisi aplikasi pembukaan tabungan haji dan slip setoran tunai lengkap beserta tanda tangan.

c. Setelah itu nasabah menghadap ke teller dan teller akan memvalidasi berkas tersebut.

d. Apabila cocok teller akan memproses transaksi dan mencetak saldo akhir dalam passbook serta memberikan bukti slip penyetoran kepada nasabah. 
Mekanisme pendaftaran kembali tabungan haji pada Bank BRI setelah dilakukan pembatalan, proses pengakuan dan pengukuran tabungan haji adalah sebagai berikut:

a. Pengakuan tabungan haji atas pendaftaran kembali setalah dilakukan pembatalan haji yaitu diakui pada saat teller menerima uang setoran awal dari nasabah. Bank mengakui setoran awal sebagai dana kewajiban nasabah. Bank tidak membebankan biaya administrasi atau bunga pada tabungan haji. Apabila nasabah ingin mendapatkan nomor porsi keberangkatan maka setoran atau saldo tabungan nasabah harus memenuhi jumlah yang telah ditentukan yaitu sebesar Rp 25.100.000,- dan pelunasannya dapat ditentukan oleh pemeritah yang berkaitan dengan kurs dollar saat itu.

b. Pengukuran tabungan haji atas pendaftaran kembali tabungan haji setelah dilakukan pembatalan diukur sebesar jumlah nilai nominal setoran awal yang tertera pada passbook tabungan haji nasabah. Sedangkan untuk transaksi pemindahbukuan agar mendapatkan nomor porsi juga diukur sesuai nilai nominalnya.

Berikut jurnal pencatatan akuntansi untuk transaksi tabungan haji yang dilakukan oleh bank :

Jurnal pada saat pembukaan rekening dan setoran awal

\begin{tabular}{|c|c|c|}
\hline Nama Akun & Debet & Kredit \\
\hline Kas & $\mathrm{xxx}$ & - \\
\hline Rekening Nasabah & - & $\mathrm{Xxx}$ \\
\hline
\end{tabular}

Artinya di debet, yaitu uang kas yang berada di bank bertambah dan rekening tabungan haji nasabah yang berada di kredit artinya saldo tabungan nasabah bertambah.

Jurnal pada saat setoran untuk mendapatkan nomor porsi keberangkatan dan terdaftar sebagai CJH di Depag

\begin{tabular}{cll}
\hline Nama Akun & Debet & Kredit \\
\hline Rekening Nasabah & $\mathrm{xxx}$ & - \\
Rekening Menteri Agama & - & $\mathrm{xxx}$ \\
\hline
\end{tabular}

Artinya di debet rekening tabungan haji adalah rekening tabungan haji nasabah yang berada di bank berkurang karena dipindahbukukan ke rekening Menteri Agama Kantor Pusat.

Mekanisme Pengungkapan Tabungan Haji. Tabungan haji pada bank BRI Soasio pada saat pembatalan haji diakui pada saat nasabah melakukan pembatalan haji dan penutupan rekening tabungan haji dan dicatat sebagai kewajiban bank atas pembatalan haji dan penutupan rekening tabungan haji. Tabungan haji diukur sebesar jumlah nilai yang ada pada passbook tabungan haji. Pihak bank tidak mengenakan potongan dan bunga pada tabungan haji. Pada saat terjadi pembatalan haji, pihak bank akan mengembalikan uang tabungan haji nasabah sesuai prosedur yang berlaku. Pengembalian uang tabungan haji dikenakan biaya administrasi. Setelah dicatat dan diukur tabungan haji juga disajikan dalam laporan keuangan posisi neraca. Tabungan haji juga harus diungkapkan dalam Catatan Atas Laporan Keuangan sehingga dapat memberikan informasi yang relevan dan akurat mengenai seluruh transanski dari tabungan haji yang diterima atau dikeluarkan. Namun, pihak Bank BRI Soasio hanya menyajikan tabungan haji pada neraca dalam laporan keuangan dan diungkapkan sebesar jumlah yang disetorkan nasabah. 


\subsection{Pembahasan}

Mekanisme Pengakuan dan Pengukuran Tabungan haji Atas Pembatalan Haji Sebelum Nasabah Terdaftar di Departemen Agama. Berdasarkan hasil penelitian yang telah dilakukan pada Bank BRI Soasio bahwa perlakuan akuntansi tabungan haji mengacu kepada Prinsip Akuntasi Berlaku Umum (PABU). Perlakuan akuntansi atas tabungan haji pada bank BRI Soasio meliputi pengakuan, pengukuran dan pengungkapan. Mekanisme pengakuan tabungan haji atas pembatalan haji yang dilakukan nasabah sebelum terdaftar sebagai Calon Jamaah Haji (CJH) di Depertemen Agama sesuai dengan Prinsip Akuntansi Berlaku Umum (PABU) yaitu diakui pada saat nasabah melakukan pembatalan haji dan penutupan rekening tabungan haji. setelah itu pihak bank harus mengembalikan uang tabungan haji nasabah. Pengembalian uang tabungan tersebut oleh pihak bank dicatat sebagai kewajiban bank karena nasabah telah melakukan pembatalan haji dan penutupan rekening. Kewajiban tersebut timbul ketika nasabah menyetorkan uang kepada bank pada saat setoran awal maupun setoran ketika mendapatkan nomor porsi keberangkan haji. Oleh sebab itu, pada saat terjadi pembatalan haji dan penutupan rekening tabungan haji, bank wajib mengembalikan uang tabungan haji tersebut kepada nasabah. Mekanisme pengukuran tabungan haji diukur sebesar jumlah nilai pada passbook tabungan haji dan dikurangi dengan biaya administrasi atas penutupan rekening tabungan haji. Jumlah nilai atau saldo pada tabungan haji nasabah tidak akan berkurang ataupun bertambah karena tabungan haji tidak dikenakan biaya administrasi bulanan ataupun bunga tabungan. Oleh karena itu, saldo dalam tabungan haji nasabah akan selalu sama sebesar jumlah yang telah disetorkan nasabah. Pihak bank hanya mengenakan biaya administrasi tabungan haji ketika nasabah membatalkan haji dan menutup rekening tabungan haji nasabah. Biaya administrasi penutupan tabungan haji dijadikan saldo mengendap sehingga pemilik tabungan tidak dapat menarik atau mengambil uang tersebut. Biaya administrasi yang dikenakan bank BRI pada tabungan haji sebesar Rp $50.000,-$.

Mekanisme Pengakuan dan Pengukuran Tabungan haji Atas Pembatalan Haji Setelah Nasabah Terdaftar di Departemen Agama. Mekanisme pengakuan tabungan haji atas pembatalan haji yang dilakukan nasabah setelah terdaftar sebagai Calon Jamaah Haji $(\mathrm{CJH})$ di Depertemen Agama sesuai dengan Prinsip Akuntansi Berlaku Umum (PABU) yaitu diakui pada saat nasabah melakukan pembatalan haji dan penutupan rekening tabungan haji. Pengakuan akuntansi tabungan haji atas pembatalan haji setelah nasabah terdaftar sebagai CJH di Depag sama dengan pengakuan sebelum terdaftar. Perbedaannya terdapat pada mekanisme pembatalan haji. Jika nasabah telah terdaftar di Depag maka nasabah harus terlebih dahulu menyelesaikan pembatalan haji dengan pihak Depag dan menerima surat pemberitahuan pembatalan haji dari Depag. Setelah itu, nasabah dapat melakukan proses pengembalian uang tabungan dengan pihak bank. Pengembalian uang tabungan tersebut dilakukan setelah nasabah mengisi formulir penutupan rekening tabungan haji. Pengembalian uang tabungan tersebut oleh pihak bank dicatat sebagai kewajiban bank karena nasabah telah melakukan pembatalan haji dan penutupan rekening. Kewajiban tersebut timbul ketika nasabah menyetorkan uang kepada bank pada saat setoran awal maupun setoran ketika mendapatkan nomor porsi keberangkan haji. Oleh sebab itu, pada saat terjadi pembatalan haji dan penutupan rekening tabungan haji bank wajib mengembalikan uang tabungan haji tersebut kepada nasabah. Mekanisme pengukuran tabungan haji diawali ketika nasabah menyetorkan uang tabungan haji pada saat pembukaan rekening tabungan haji. Jumlah nilai atau saldo pada tabungan haji nasabah tidak akan berkurang ataupun bertambah karena tabungan haji tidak dikenakan biaya administrasi bulanan ataupun bunga tabungan. Oleh karena itu, saldo dalam tabungan haji nasabah akan selalu sama sebesar jumlah yang telah disetorkan nasabah. Pihak bank hanya mengenakan biaya administrasi tabungan haji ketika nasabah membatalkan haji dan menutup rekening tabungan haji nasabah. Biaya administrasi 
penutupan tabungan haji dijadikan saldo mengendap sehingga pemilik tabungan tidak dapat menarik atau mengambil uang tersebut. Biaya administrasi yang dikenakan bank BRI pada tabungan haji sebesar Rp 50.000,-. Pada saat nasabah melakukan pembatalan haji, tabungan haji diukur sebesar jumlah nilai pada passbook tabungan haji dan dikurangi dengan biaya administrasi atas penutupan rekening tabungan haji.

Mekanisme Pengakuan dan Pengukuran Pendaftaran Kembali Tabungan Haji Setelah Pembatalan. Berdasarkan hasil penelitian yang telah dilakukan pada Bank BRI Soasio bahwa perlakuan akuntansi tabungan haji mengacu kepada Prinsip Akuntasi Berlaku Umum (PABU). Perlakuan akuntansi atas tabungan haji pada bank BRI Soasio meliputi pengakuan, pengukuran dan pengungkapan. Mekanisme pengakuan tabungan haji atas pendaftaran kembali setalah dilakukan pembatalan haji yaitu diakui pada saat teller menerima uang setoran awal dari nasabah. Sebelum menyetorkan uang kepada teller, nasabah harus terlebih dahulu melakukan pembukaan rekening tabungan haji di bagian Costumer Service. Setoran awal nasabah minimal Rp 100.000,- namun jika nasabah ingin langsung mendapatkan nomor porsi keberangkatan haji maka nasabah harus menyetorkan uang sebesar Rp 25.100.000,- kepada teller. Bank mengakui setoran awal sebagai dana kewajiban nasabah. Bank tidak membebankan biaya administrasi atau bunga pada tabungan haji. Mekanisme pengukuran tabungan haji atas pendaftaran kembali tabungan haji setelah dilakukan pembatalan diukur sebesar jumlah nilai nominal setoran awal yang tertera pada passbook tabungan haji nasabah. Sedangkan untuk transaksi pemindahbukuan agar mendapatkan nomor porsi juga diukur sesuai nilai nominalnya.

Mekanisme Pengungkapan Tabungan Haji. Berdasarkan hasil penelitian yang telah dilakukan pada Bank BRI Soasio bahwa perlakuan akuntansi tabungan haji mengacu kepada Prinsip Akuntasi Berlaku Umum (PABU). Perlakuan akuntansi atas tabungan haji pada bank BRI Soasio meliputi pengakuan, pengukuran dan pengungkapan. Mekanisme pengungkapan tabungan haji pada bank BRI dilakukan setelah proses pengakuan dan pengukuran. Pada saat terjadinya pembatalan haji dan penutupan rekening tabungan haji, pihak bank mengakui sebagai kewajiban dan diukur sebesar jumlah nilai yang tertera pada passbook tabungan haji dan kemudian tabungan haji diungkapkan dalam laporan keuangan. Bank BRI Soasio menyajikan dan mengungkakan tabungan haji dalam laporan keuangan hanya pada posisi neraca dan tidak diungkapkan pada Catatan Atas Laporan Keuangan. Berdasarkan Prinsip Akuntansi Berlaku Umum (PABU) tabungan atau simpanan disajikan dan diungkapakan dalam laporan keuangan pada posisi neraca dan Catatan Atas Laporan Keuangan sehingga dapat memberikan informasi yang relevan dan akurat mengenai seluruh transanski dari tabungan haji yang diterima atau dikeluarkan.

Berikut perbandingan perlakuan akuntansi tabungan haji oleh bank BRI Soasio dengan Prinsip Akuntansi Berlaku Umum (PABU). 
Tabel 1. Perbandingan perlakuan akuntansi tabungan haji oleh bank BRI dan PABU

\begin{tabular}{|c|c|c|}
\hline Berdasarkan PABU & $\begin{array}{c}\text { Berdasarkan Bank Rakyat } \\
\text { Indonesia (BRI) }\end{array}$ & Kesimpulan \\
\hline $\begin{array}{l}\text { Simpanan/tabungan/dana pihak ketiga } \\
\text { diakui sebagai kewajiban dan diakui } \\
\text { pada saat uang diterima oleh pihak } \\
\text { bank }\end{array}$ & $\begin{array}{l}\text { Tabungan haji diakui sebagai } \\
\text { kewajiban dan diakui pada saat } \\
\text { nasabah melakukan setoran dan } \\
\text { diterima oleh pihak bank }\end{array}$ & $\begin{array}{l}\text { Sesuai. Karena baik menurut } \\
\text { bank maupun PABU, tabungan } \\
\text { diakui sebagai kewajiban bank } \\
\text { pada saat bank menerima } \\
\text { setoran dari nasabah. }\end{array}$ \\
\hline $\begin{array}{l}\text { Simpanan/tabungan/dana pihak ketiga } \\
\text { diukur pada nilai wajar melalui } \\
\text { laporan laba rugi, diukur sebesar } \\
\text { (nominal) simpanan/tabungan }\end{array}$ & $\begin{array}{l}\text { Tabungan haji dukur sebesar } \\
\text { nominal pada simpanan, namun } \\
\text { pada saat pembatalan haji dan } \\
\text { penutupan rekening bank } \\
\text { mengenakan biaya administrasi } \\
\text { penutupan rekening. Tabungan haji } \\
\text { juga tidak diukur melalui laba rugi. }\end{array}$ & $\begin{array}{l}\text { Belum sesuai. Karena pada } \\
\text { tabungan haji BRI tidak diukur } \\
\text { melalui laporan laba rugi }\end{array}$ \\
\hline $\begin{array}{l}\text { Simpanan/tabungan/dana pihak ketiga } \\
\text { disajikan dan diungkapkan dalam } \\
\text { laporan keuangan posisi neraca sesuai } \\
\text { kategori kewajiban keuangan }\end{array}$ & $\begin{array}{l}\text { Tabungan haji diungkapkan dalam } \\
\text { laporan keuangan posisi neraca } \\
\text { dengan akun tabungan haji. } \\
\text { Disajikan disisi pasiva karena } \\
\text { tabungan merupakan kewajiban } \\
\text { bank kepada nasabah }\end{array}$ & $\begin{array}{l}\text { Sesuai. Karena berdasarkan } \\
\text { bank dan PABU tabungan haji } \\
\text { disajikan dan diungkapkan } \\
\text { dalam laporan keuangan posisi } \\
\text { neraca. }\end{array}$ \\
\hline
\end{tabular}

\section{KESIMPULAN DAN SARAN}

\subsection{Kesimpulan}

Berdasarkan hasil penelitian mengenai mekanisme perlakuan akuntansi tabungan haji khususnya perlakuan akuntansi tabungan haji pada saat pembatalan haji sebelum dan setelah nasabah terdaftar sebagai calon jamaah haji di Departemen Agama serta mekanisme perlakuan akuntansi atas pendaftaran kembali tabungan haji setelah dilakukan pembatalan haji di Bank BRI Soasio, maka penulis menarik kesimpulan yang terkait dengan hasil penelitian, yaitu sebagai berikut:

1. Perlakuan akuntansi tabungan haji pada PT. Bank Rakyat Indonesia (Persero) Tbk Kantor Cabang Soasio mengacu pada Prinsip Akuntansi Berlaku Umum (PABU).

2. Mekanisme perlakuan akuntansi tabungan haji atas pembatalan haji sebelum dan setelah nasabah terdaftar sebagai CJH di Depag, pengakuan tabungan haji pada saat pembatalan haji diakui pada saat nasabah melakukan pembatalan haji dan penutupan rekening tabungan haji,, bank mencatat sebagai kewajiban atas pembatalan haji dan penutupan rekening tabungan haji. Tabungan haji diukur sebesar jumlah nilai yang tertera pada passbook tabungan haji nasabah setelah dikurangi biaya administrasi.

3. Mekanisme perlakuan akuntansi tabungan haji atas pendaftaran kembali setelah dilakukan pembatalan haji, pengakuan tabungan haji pada saat pendaftaran kembali diakui pada saat teller menerima uang setoran awal dari nasabah dan bank mengakuii setoran awal sebagai dana kewajiban nasabah. Tabungan haji pada saat pendaftaran diukur sebesar jumlah nilai nominal setoran awal yang tertera pada passbook tabungan haji.

4. Pengakuan dan pengukuran tabungan haji ini dikelompokkan menjadi tahap, yaitu : (a) saat pendaftaran dan pembukaan tabungan haji; (b) saat penyetoran awal BPIH (Biaya Pelunasan Ibadah Haji); (c) saat penyetoran untuk mendapatkan nomor porsi keberangkatan; (d) saat pembatalan sebelum terdaftar ke Departemen Agama; (e) saat pembatalan setelah terdaftar ke Departemen Agama; (f) saat penutupan rekening tabungan haji 
5. Tabungan Haji pada Bank BRI disajikan dalam laporan keuangan bagian neraca pada kelompok pasiva sebesar nilai nominalnya dan hanya diungkapkan dalam kelompok neraca

Adapun keterbatasan dalam penelitian ini adalah :

1. Pada saat akan melakukan wawancara secara langsung, pihak bank tidak memberikan keleluasaan untuk bertanya secara mendalam tentang tabungan haji.

2. Penjurnalan transaksi pada bank dilakukan oleh program, dan pihak bank tidak bersedia memberikan print outnya, pihak bank hanya memberikan gambaran-gambarannya saja.

\subsection{Saran}

Berdasarkan analisis data yang telah dibahas sebelumnya, maka penulis memberikan saran antara lain :

1. Sebaiknya pihak Bank BRI Soasio memberikan training lagi kepada pada pegawainya, terutama bagian akuntansi, agar lebih memahami tentang jurnal secara manual, meskipun pengolahannya dilakukan oleh program.

2. Saran untuk peneliti selanjutnya, sebelum memutuskan untuk mengambil penelitian tentang perlakuan akuntansi dan tabungan haji sebaiknya peneliti yang akan datang telah menguasai teori tentang perlakuan akuntansi dan tabungan haji dan telah memiliki gambaran tentang lokasi penelitiannya, agar penelitian dapat berjalan dengan lancar.

\section{DAFTAR PUSTAKA}

Tanor, M. 2015. Analisis Laporan Keuangan Dalam Mengukur Kinerja Keuangan Pada PT. Bank Artha Graha International Tbk. Skripsi. Universitas Sam Ratulangi. Manado.

BINUS University. 2016. Inilah Pengertian Akuntansi Keuangan dan Fungsinya Secara Umum. Https://accounting.binus.ac.id/2016/08/31/inilah-pengertian-akuntansikeuangan-dan-fungsinya-secara-umum/. 16 September (12:21).

Flood, J. M. 2014. Willey GAAP 2014: Interpretation and Application Of Generally Accepted Accounting Principles. Willey. USA.

Kholid, H. 2013. Produk Perbankan Syariah di Bidang Penghimpunan Dana Dari Masyarakat (Funding).http://hendrakholid.net/blog/2009/10/29/produk-perbankan syariah-dibidang-penghimpunan-dana-dari-masyarakat-founding/. 05 Mei 2018 (20:18).

Undang-Undang Republik Indonesia Nomor 5 Tahun 2018 Pelaksanaan Undang-Undang Nomor 34 Tahun 2014 Tentang Pengelolaan Keuangan Haji. 17 Oktober 2014. Tambahan Lembaran Negara Republik Indonesia Nomor 6182.

Undang-Undang Republik Indonesia Nomor 10 Tahun 1998 Perubahan Atas Undang-Undang Nomor 7 Tahun 1992 Tentang Perbankan. 10 Oktober 1998. Tambahan Lembaran Negara Republik Indonesia Nomor 3790.

Setiawan, A. 2018. Syarat dan Ketentuan Membuka Tabungan Haji BRI. http://www.infpperbankan.com/bri/syarat-dan-ketentuan-membuka-tabungan-hajibri.html/amp. 13 Mei 2018 (13:21).

Astari, R. 2013. Perlakuan Akuntansi Tabungan Haji Pada PT. Bank Rakyat Indonesia. Tbk Cabang Sidoarjo. Skripsi. STIE Perbanas. Surabaya.

Subianto, A. 2016. Menata Kembali Manajemen Haji Indonesia. YAKAMUS dan Gibon Books. Jakarta.

Daulay, N. 2017. Faktor-Faktor Yang Berhubungan Dengan Perkembangan Produk Tabungan Haji Perbankan Syariah di Indonesia. Human Falah 4(1): 105-136.

Oktarini, E. 2016. Faktor-Faktor Yang Mempengaruhi Keputusan Nasabah Membuka Tabungan Haji di Bank Muamalat Indonesia Cabang Sungailiat. STUDIA 1(1): 64-74.

Wahyuningsih, I. dan N.S. IMM. 2012. Perlakuan Akuntansi Tabungan Haji Pada Bank Mega Syariah di Surabaya. The Indonesian Accounting Review 2(2): 243-256. 